medRxiv preprint doi: https://doi.org/10.1101/2021.05.31.21258118; this version posted June 1, 2021. The copyright holder for this preprint (which was not certified by peer review) is the author/funder, who has granted medRxiv a license to display the preprint in perpetuity. It is made available under a CC-BY-NC-ND 4.0 International license .

\title{
Epidemiological profile study of COVID-19 in West African countries: Nigeria, Senegal, Mauritania, Cape Verde and Mali
}

Mouhamadou Faly Ba ${ }^{1, *}$, Boly Diop ${ }^{2}$, Oumar Bassoum ${ }^{1}$, Ndèye Marème Sougou ${ }^{1}$, Khadim Niang ${ }^{1}$, Emmanuel Bonnet $^{3}$, Valéry Ridde ${ }^{3}$, Adama Faye ${ }^{1}$

${ }^{1}$ Institut de Santé et Développement, Université Cheikh Anta Diop de Dakar, Sénégal

${ }^{2}$ Direction de la Prévention, Ministère de la Santé et de l'Action Sociale, Sénégal

${ }^{3}$ Institut de Recherché pour le Développement (IRD)

* Corresponding author(s)

Email address: falyba1@ gmail.com (M.F. Ba)

ORCID ID: https://orcid.org/0000-0002-1898-738X

\begin{abstract}
Introduction: The COVID-19 pandemic was first reported in West Africa on 27 February 2020 in Nigeria. It subsequently spread to other countries in the region. The objective of this study is to analyze the epidemiological profile of COVID-19 in West Africa from the first reported case to 31 January 2021.
\end{abstract}

Method: We publicly used available data from reliable sources and from the "COVID-19R" package. We used epidemic curves to describe the trends in the daily evolution of confirmed cases and deaths of COVID-19 in West Africa and specifically in the five countries. The reproduction rate and evolution rates were calculated from these trends.

Results: As of 31 January 2021, West Africa had 342,938 confirmed cases of COVID-19 with 4,496 deaths. Nigeria had 131,242 cases with 1,586 deaths. Senegal had 26,523 cases with 628 deaths. The case-fatality rate in Mali was $4.08 \%$ and the attack rate in Cape Verde was 2587 cases per 100,000 inhabitants. In Nigeria, Senegal, Mauritania and Mali, the epidemic curves supported by the evolution rates showed an increase in confirmed cases and deaths of COVID19 during December 2020 and January 2021 compared to the last two months. The effective reproduction rates $\left(R_{e}\right)$ inferred a slowdown in virus transmission $\left(R_{e}<1\right)$ in these countries except for Senegal.

Conclusion: The results showed that COVID-19 was still circulating in some West African countries in late 2020 and early 2021. By improving the health system and with context-specific public health interventions and vaccination, these countries should effectively control COVID19.

Keywords: Epidemiology, COVID-19, West Africa, Countries 
medRxiv preprint doi: https://doi.org/10.1101/2021.05.31.21258118; this version posted June 1, 2021. The copyright holder for this preprint (which was not certified by peer review) is the author/funder, who has granted medRxiv a license to display the preprint in perpetuity. It is made available under a CC-BY-NC-ND 4.0 International license.

\section{INTRODUCTION}

Coronavirus disease 2019 (COVID-19) has spread rapidly across all continents, and the number of confirmed cases and deaths has increased worldwide [1]. It is the most devastating pandemic that humanity has experienced in the last ten decades [2]. In fact, no other pandemic has taken so many lives in the same time period [2].

Africa confirmed its first case of COVID-19 in Egypt on 14 February 2020 [3]. On 27 February 2020, Nigeria reported the first official case of severe acute respiratory syndrome coronavirus 2 (SARS-CoV-2) in the West African region [4]. On 18 March 2020, Burkina Faso reported the first death [5]. Most West African countries were quick to take measures to limit gatherings and build public health capacity. As a result, the number of cases and deaths has remained lower than in other parts of the world [6-8] despite dire predictions [9]. As stated in the World Health Organization's draft guidance document on infection prevention and control, it was imperative that member countries strictly adhere to standard precautions for all infected persons, and it was also recommended that a coordinating center for infection prevention and control be established, with the support of senior country and institutional leadership $[10,11]$.

Despite the relatively low spread of COVID-19 in African countries [2], there was a marked increase in cases between December 2020 and January 2021 [12]. On average, 25,223 cases were reported daily between 28 December 2020 and 10 January 2021 in Africa, almost 39\% higher than the peak of 18,104 daily cases averaged over two weeks in July 2020 [13]. In West Africa, the first wave had challenged the health system, leading to its saturation. This led Senegal, for example, to opt for home-based management of simple cases [14], which entailed a number of risks, notably the spread of the virus within households and in the community [15]. The most severe 'second wave' coincided with the emergence of new British and South African variants [16].

Therefore, the estimation of epidemiological measures of coronavirus disease 2019 (COVID19) is important to assess the extent of epidemic transmission. These results will be useful for policy makers, both at the national and supranational level, to further plan and evaluate measures to contain the spread of the ongoing epidemic. Furthermore, this type of study on the dynamics of the COVID-19 pandemic in West Africa is very limited. The objective is to assess the epidemiological profile of COVID-19 in West African countries from 27 February 2020 (first reported case) to 31 January 2021.

\section{METHOD}

The United Nations defines West Africa as the following 16 countries: Benin, Burkina Faso, Cape Verde, Gambia, Ghana, Guinea, Guinea-Bissau, Ivory Coast, Liberia, Mali, Mauritania, Niger, Nigeria, Senegal, Sierra Leone and Togo [17]. The total population of this region is estimated to be around 381 million people in 2018 [18]. Health is a fundamental issue for West African countries. However, due to their level of development, they do not have health systems adapted to the needs of their populations [19]. This structural deficiency is generally perceptible in the difficulties encountered by states in containing endogenous health threats and combating the major infectious diseases such as HIV and tuberculosis that are rampant in the region [19]. 
medRxiv preprint doi: https://doi.org/10.1101/2021.05.31.21258118; this version posted June 1, 2021. The copyright holder for this preprint

(which was not certified by peer review) is the author/funder, who has granted medRxiv a license to display the preprint in perpetuity.

It is made available under a CC-BY-NC-ND 4.0 International license .

We used the "COVID19R" package, available on the Comprehensive R Archive Network (CRAN), to obtain the data [20]. This package unifies COVID-19 datasets from different sources to simplify the data acquisition process and subsequent analysis [21]. The COVID-19 data are extracted in real time from several reliable sources, including: Johns Hopkins University Center for Systems Science and Engineering (JHU CSSE); World Bank Open Data; World Factbook by CIA; Ministero della Salute, Dipartimento della Protezione Civile; ISTAT - Istituto Nazionale di Statistica; Swiss Federal Statistical Office; Open Government Data Zurich [21].

The epidemiological data for this study included the cumulative number of daily cases of COVID-19 and the daily number of deaths. The study period was from 28 February 2020, the date of the first case detected in the study area (Nigeria) to 31 January 2021. The data covered West Africa as a whole and five countries within it: Nigeria, Senegal, Mauritania, Mali and Cape Verde. These countries were selected on the basis of population (Nigeria), area (Mali), density (inhabitants $/ \mathrm{km}^{2}$ ) (Nigeria, Cape Verde and Mauritania), languages spoken (Portuguese, French and English speaking countries) and geographical location (Cape Verde and Senegal) [22].

The analysis was carried out with the R software version 4.0.3 and focused on the following elements:

- The number of confirmed cases of COVID-19

- Cumulative number of COVID-19 deaths

- Case fatality rate by country and globally: proportion of COVID-19-related deaths to the total number of confirmed cases of COVID-19

- Attack rate per 100,000 inhabitants: This is determined by the ratio of the number of confirmed cases of COVID-19 to the total population, multiplied by 100,000

- Epidemic curves by epidemiological week for confirmed cases and deaths of COVID-19: These will allow the trend to be seen globally.

- Effective reproduction rate $\mathrm{R}_{\mathrm{e}}$ : The reproduction rate is defined as the average number of new illnesses caused by an infected person in a population [1]. The effective $\mathrm{R}$ is an indicator of the virus transmission dynamics about 1 week before integrating the serial interval. This parameter was estimated using the "EpiEstim" package [23]. We assume that the serial interval distribution follows the gamma distribution with a means of 4.8 and a standard deviation of 2.3 given by Nishiura $H$ et al [24]. For $R_{e}>1$, the number of infected patients is likely to increase and for $\mathrm{R}_{\mathrm{e}}<1$, transmission is likely to slow down.

- Rates of change in confirmed cases and deaths: This consists of estimating the change in the epidemic in December 2020 and January 2021 compared to October and November 2020. 
medRxiv preprint doi: https://doi.org/10.1101/2021.05.31.21258118; this version posted June 1, 2021. The copyright holder for this preprint (which was not certified by peer review) is the author/funder, who has granted medRxiv a license to display the preprint in perpetuity.

It is made available under a CC-BY-NC-ND 4.0 International license.

\section{RESULTS}

As of 31 January 2021, West Africa had 342,938 confirmed cases of COVID-19 with 4,496 deaths. It had a case-fatality of $1.31 \%$ during this period with an attack rate of 89.96 cases per 100,000 inhabitants. Nigeria and Senegal had 131,242 and 26,523 cases respectively (Figure 1).

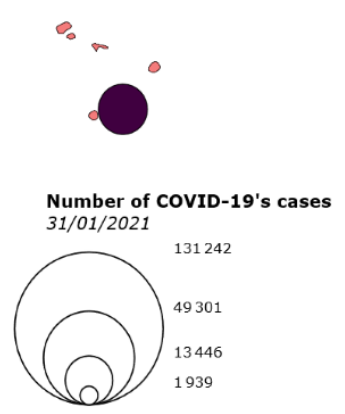

Study area

$200 \mathrm{~km}$

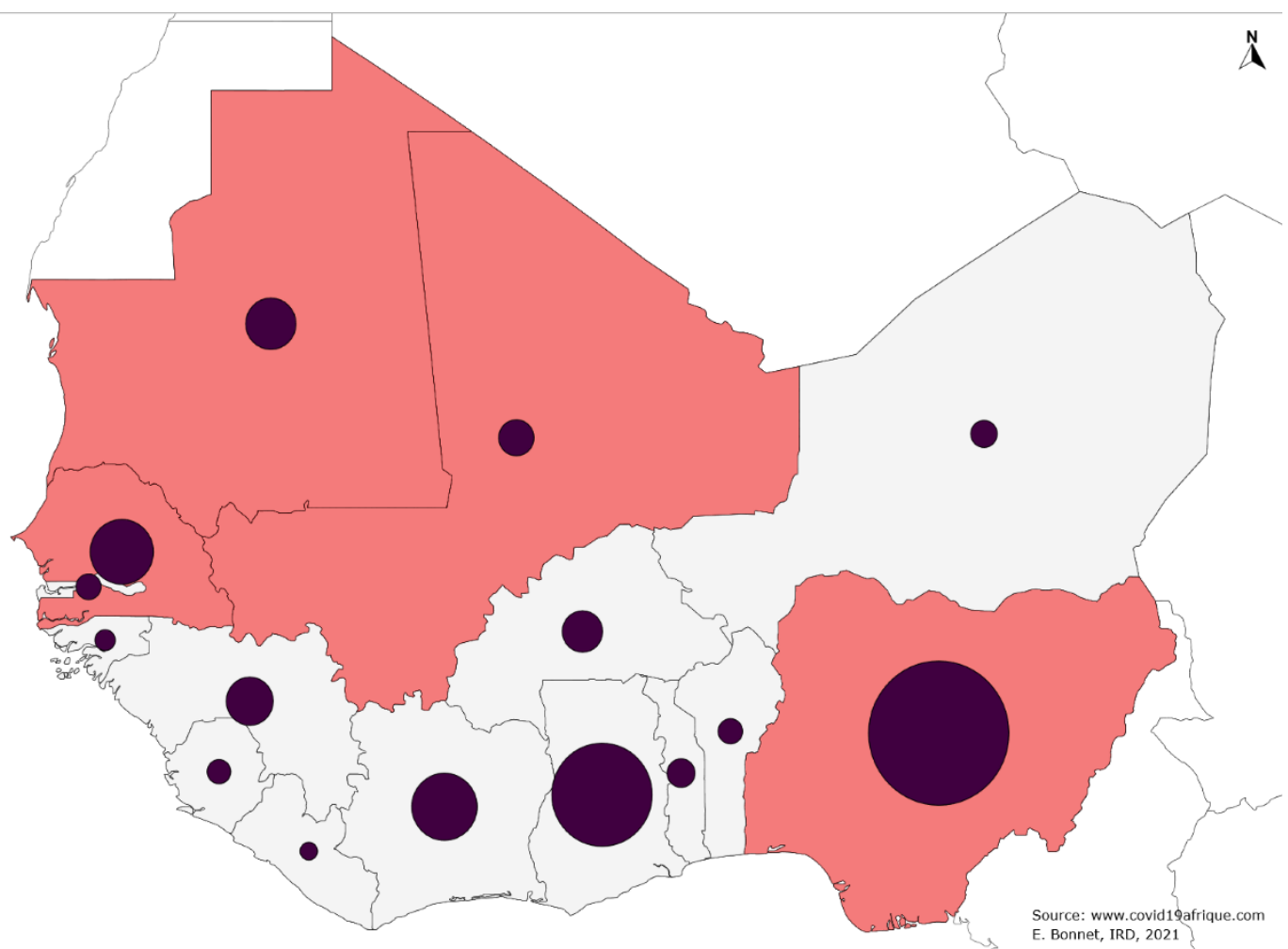

Source: www.covid19afrique.com

Figure 1: Distribution of the number of cases by country in West Africa to 31 January 2021

Nigeria had the highest number of deaths from COVID-19 with 1,586 deaths followed by Senegal with 628 deaths. Mali had a case fatality rate of $4.08 \%$. The attack rate in Cape Verde was far ahead of all other countries and corresponded to 2,587.51 cases per 100,000 inhabitants (Table 1).

Table 1: Status of COVID-19 from 28 February 2020 to 31 January 2021

\begin{tabular}{|lcccc|}
\hline Country & Deaths & Population & $\begin{array}{c}\text { Case fatality rate } \\
(\mathbf{\%})\end{array}$ & $\begin{array}{c}\text { Attack rate per } \\
\mathbf{1 0 0 , 0 0 0} \text { inhabitants }\end{array}$ \\
\hline Nigeria & 1586 & 195874740 & 1,21 & 67,00 \\
\hline Senegal & 628 & 15854360 & 2,37 & 167,29 \\
\hline Mauritania & 422 & 4403319 & 2,54 & 377,78 \\
\hline Cabo Verde & 134 & 543767 & 0,95 & 2587,51 \\
\hline Mali & 330 & 19077690 & 4,08 & 42,41 \\
\hline West Africa & $\mathbf{4 4 9 6}$ & $\mathbf{3 8 1 1 9 6 8 6 9}$ & $\mathbf{1 , 3 1}$ & $\mathbf{8 9 , 9 6}$ \\
\hline
\end{tabular}


medRxiv preprint doi: https://doi.org/10.1101/2021.05.31.21258118; this version posted June 1, 2021. The copyright holder for this preprint (which was not certified by peer review) is the author/funder, who has granted medRxiv a license to display the preprint in perpetuity.

It is made available under a CC-BY-NC-ND 4.0 International license .

The epidemic curves of confirmed cases and deaths of COVID-19 showed the same trends (Figure 2).
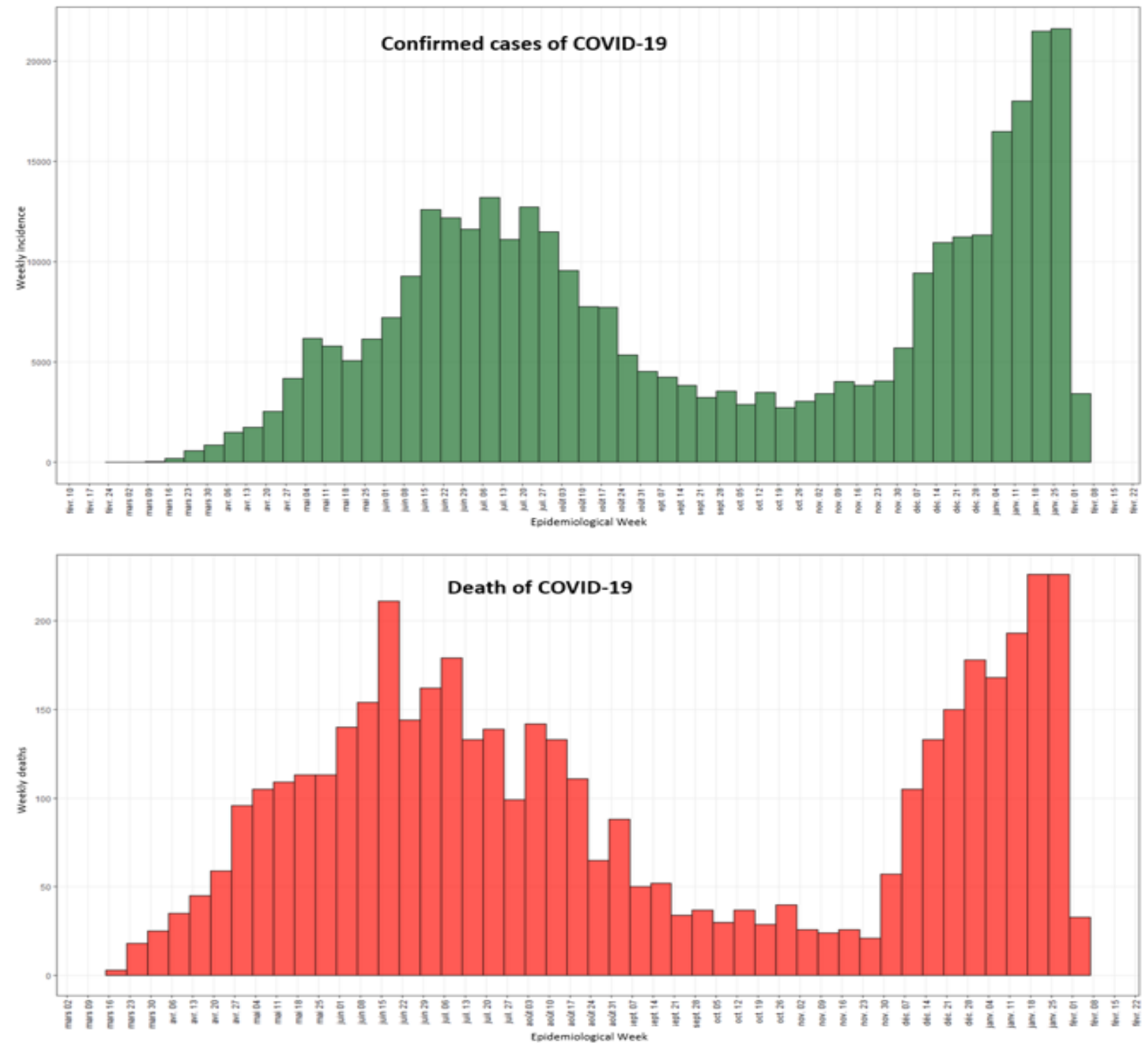

Figure 2: Epidemic curves by epidemiological week for confirmed cases and deaths of COVID-19 in West Africa, 28 February 2020 to 31 January 2021

In Figures 2 and 3, this trend was the same in Nigeria, Senegal, Mauritania and Mali with two waves observed over two different periods. There was a clear trend in confirmed cases and deaths of COVID-19 in these four countries during the period December 2020 to January 2021. For confirmed COVID-19 cases, the rate of change ranged from $842.55 \%$ (Senegal) to $112.37 \%$ (Mali). For COVID-19 deaths, they ranged from 1431.25\% (Mauritania) to 577.05\% (Nigeria) (Appendix 1 and 2). The evolution of deaths during the second wave was less important in Nigeria compared to the first "wave" (Figure 3). In addition, the Re in Nigeria, Mauritania and Mali was 0.88 [0.86 - 0.90], 0.77 [0.67 - 0.87] and 0.78 [0.64 - 0.94] respectively, showing a slowdown in virus transmission in these areas (Appendix 1). 


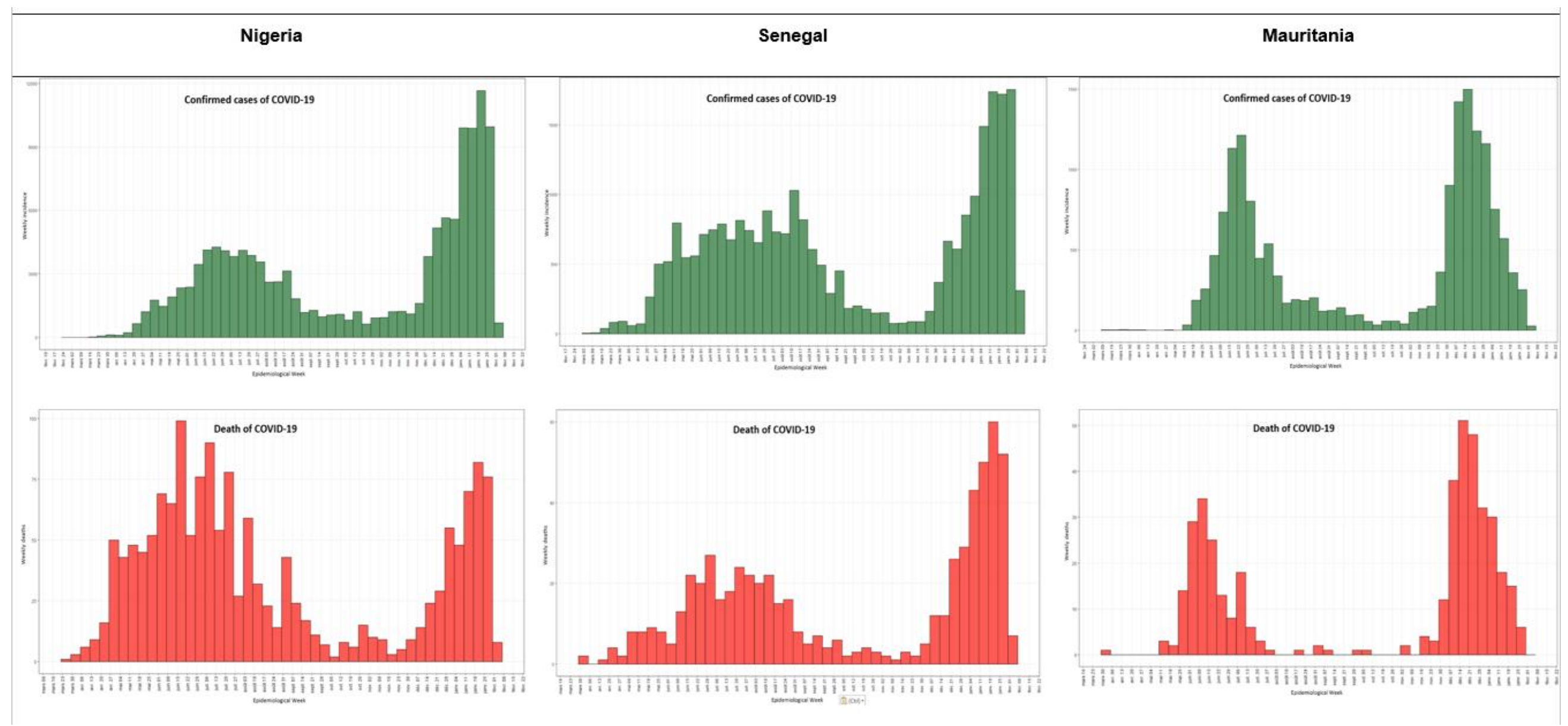

Figure 3: Epidemic curves by week of confirmed cases and deaths of COVID-19 in Nigeria, Senegal and Mauritania, from 28 February 2020 to 31 January 2021 
medRxiv preprint doi: https://doi.org/10.1101/2021.05.31.21258118; this version posted June 1, 2021. The copyright holder for this preprint (which was not certified by peer review) is the author/funder, who has granted medRxiv a license to display the preprint in perpetuity.

It is made available under a CC-BY-NC-ND 4.0 International license .

In Cape Verde, this trend was less clear (Figure 4) and there was even a lower evolution of COVID-19 cases and deaths in December 2020 and January 2021 (-30.15\% and -35.56\% respectively) compared to October and November 2020 (Appendix 1 and 2). However, the Re in Cape Verde was 1.15 [1.05 - 1.25] demonstrating the evolution of the virus transmission in the area during the last week of January 2021 (Appendix 2).
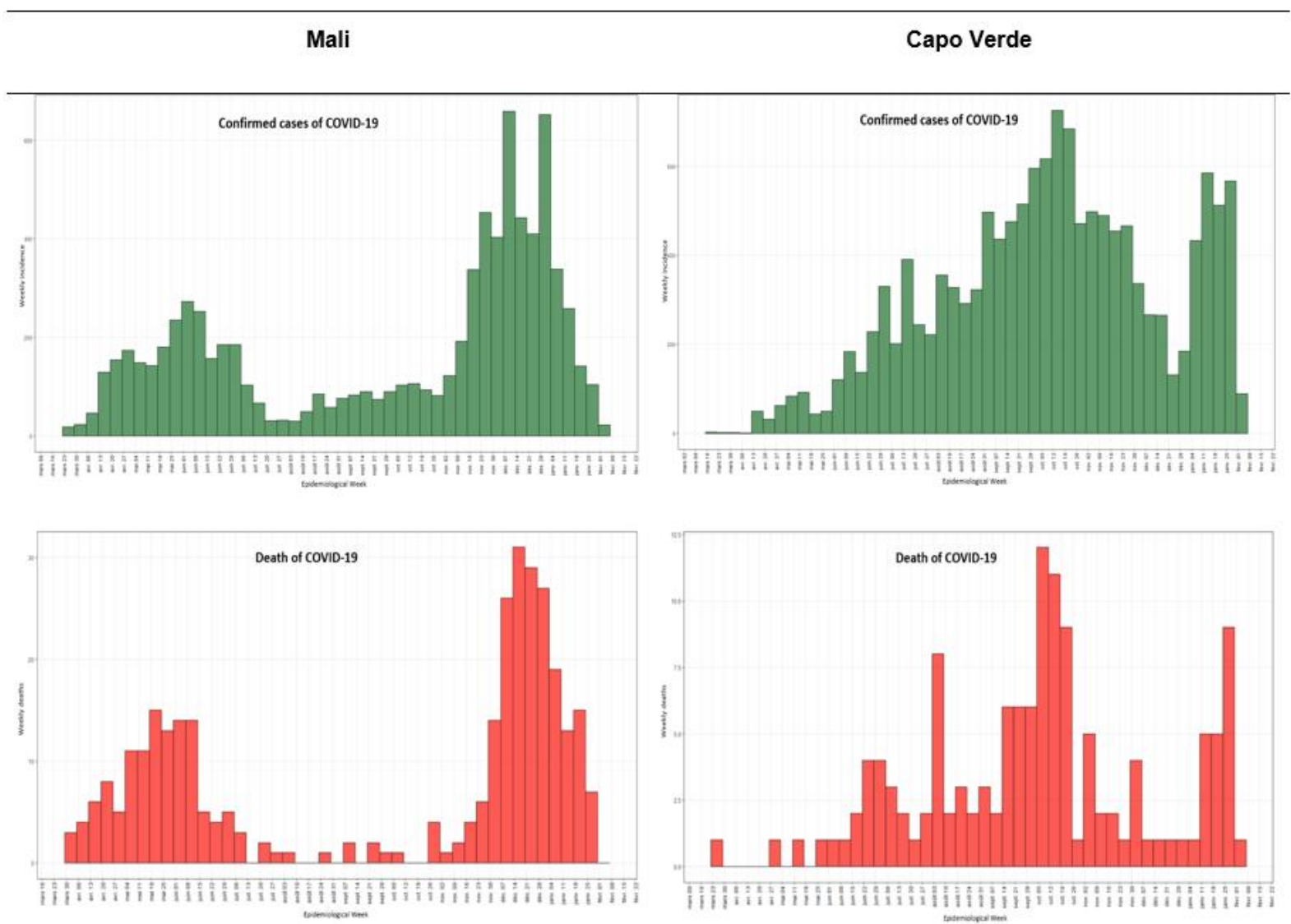

Figure 4: Epidemic curves by week of confirmed cases and deaths of COVID-19 in Mali and Cape Verde, 28 February 2020 to 31 January 2021 
medRxiv preprint doi: https://doi.org/10.1101/2021.05.31.21258118; this version posted June 1, 2021. The copyright holder for this preprint (which was not certified by peer review) is the author/funder, who has granted medRxiv a license to display the preprint in perpetuity. It is made available under a CC-BY-NC-ND 4.0 International license .

\section{DISCUSSION}

This study analyzed the epidemiological profile of COVID-19 in some West African countries. It dealt with the static and dynamic parameters of the epidemic. Globally, transmission of the virus persists, and countries continue to employ various strategies to control the COVID-19 pandemic. In this regard, several countries in West Africa had developed their response plans to elaborate their responses [25]. Thus, they had set up several governmental measures, either before like Nigeria or Burkina Faso [7,26], or coincidentally with the diagnosis of the first national cases. These measures included temperature control in airports, curfews, prohibition of travel between regions, wearing of masks, closure of schools and markets $[7,8,26]$, etc. These different measures did not lead to the development of a national strategy for the prevention of the disease. These various measures did not fully limit the spread of the virus. Although empirical estimates based on the data are not ideal (data irregularities, lack of triangulation with country data, etc.), as of 31 January 2021, West Africa accounted for only $0.3 \%$ of confirmed cases and $0.2 \%$ of deaths worldwide [27]. Nigeria had the highest number of cases and the highest number of deaths. Nigeria was hit hard by the second wave, which was much larger than the first. It should be noted, however, that Nigeria is the most populous country in West Africa with almost 200 million inhabitants [18]. This may explain why it has the highest number of cases in West Africa.

The case fatality rate of COVID-19 in West Africa was lower than in Africa and the world [2729]. However, it was highly heterogeneous despite the similarity of health systems, which were characterized by inadequate financing, lack of modern and sophisticated health care facilities, inadequate or non-existent health insurance schemes, shortage of well-trained health personnel, chaotic implementation of health policies and poor access to essential services [2,30]. The causes of this variability presented in this study deserve further investigation.

The number of COVID-19 cases and deaths in West Africa had increased by $326.86 \%$ and 451.33\% respectively in December 2020 and January 2021 compared to October and November 2020. Nigeria, Senegal, Mauritania and Mali had noted this increase. This could be explained not only by the lifting of restrictive measures that were enacted by government authorities in these countries at the onset of the pandemic [26] but also by the relaxation of preventive hygiene measures [12]. It must be said that West African countries suffered great economic damage during the pandemic [31]. However, trying to revive economies and livelihoods devastated by the pandemic while at the same time aiming to limit the spread of COVID-19 is a difficult balancing act $[7,12]$. The evolution of COVID-19 cases coincides with the emergence of new variants, although at present this relationship has not been established [16].

Nevertheless, there was a $30.15 \%$ and $35.56 \%$ decrease in the number of cases and deaths in December 2020 and January 2021 respectively in Cape Verde. The particularity of Cape Verde is that it is an island state. The country had adopted pre-arrival screening in October 2020 after the closure was lifted [32]. This strategy, together with others such as the closure of schools in high transmission localities and the closure of non-essential workplaces [32], could explain the containment of the epidemic in this area. Other hypothetical determinants could explain this decrease during this period, such as the geo-climatic and micro-environmental conditions present on the island [33].

In addition, despite the trend in confirmed cases mentioned above, a decline in transmission was observed in the last week of January in Nigeria, Mauritania and Mali with reproduction 
medRxiv preprint doi: https://doi.org/10.1101/2021.05.31.21258118; this version posted June 1, 2021. The copyright holder for this preprint

(which was not certified by peer review) is the author/funder, who has granted medRxiv a license to display the preprint in perpetuity.

It is made available under a CC-BY-NC-ND 4.0 International license .

rates below 1. This is important and could mean a decline in the transmission trend in the coming weeks. This decline could be reinforced by the vaccination campaign that some have started [34,35]. In particular, it is still important to increase screening, isolate contacts and patients undergoing treatment, and reinforce proven prevention measures.

\section{Limits}

The study does not address the dynamics of the epidemic during the entire 2020 period. It does not statistically compare the magnitude of the evolution of the second wave to the first. Also, it was conducted in only 5 of the 16 countries in West Africa. However, the difference in the context of these countries (geographical location, density, language spoken, etc.) is an important aspect that makes it possible to highlight to some extent the distribution of the health problem in the area. Despite these limitations, the study provides an understanding of the transmission pattern to date and underlines the importance of epidemiological surveillance in countries affected by COVID-19. These data can be used for the planning and implementation of control measures. For this reason, surveillance and simple descriptive analysis should be continued as long as COVID-19 continues to spread.

The data in this article are from 31 January 2021 and in the future the transmission of the disease is supposed to be considered again.

\section{CONCLUSION}

Static and dynamic public health surveillance tools provide a picture of the pandemic's progress across countries and regions. Although static measures capture data at a specific point in time, such as numbers of cases and deaths, they are less successful in assessing the dynamics of the epidemic. Thus, it was important to incorporate parameters such as the rate of change and the effective reproduction rate. However, the results showed that COVID-19 was still being transmitted in West African countries. By improving the health system and with contextspecific public health interventions and vaccination, these countries could effectively control COVID-19.

\section{CONFLICT OF INTEREST}

The authors have no conflicts of interests regarding the publication of this paper.

\section{ETHICAL APPROVAL}

Ethical approval was not required

\section{AUTHORS' CONTRIBUTIONS}

MFB and AF: designed the study. MFB: analyzed the data and drafted the manuscript. BD and AF: reviewed the manuscript, and edited the final draft. OB, NMS, EB and VR: provided guidance and comments and reviewed the draft manuscript. All authors have read and agreed to the final version of this manuscript. 
medRxiv preprint doi: https://doi.org/10.1101/2021.05.31.21258118; this version posted June 1, 2021. The copyright holder for this preprint (which was not certified by peer review) is the author/funder, who has granted medRxiv a license to display the preprint in perpetuity.

\section{References:}

1. Najafi F, Izadi N, Hashemi-Nazari SS, Khosravi-Shadmani F, Nikbakht R, Shakiba E. Serial interval and time-varying reproduction number estimation for COVID-19 in western Iran. New Microbes New Infect. 2020;36:1-7.

2. Bankole TO, Omoyeni OB, Oyebode AO, Akintunde DO. Low incidence of COVID19 in the West African sub-region: mitigating healthcare delivery system or a matter of time? J Public Heal. 2020;

3. West African Health Organization. Epidemiological Information Bulletin Week 6. Bobo-Dioulasso, Burkina Faso; 2020.

4. West African Health Organization. Epidemiological Information Bulletin Week 8, Bobo-Dioulasso, Burkina Faso; 2020.

5. Mennechet FJD, Dzomo GRT. Coping with COVID-19 in Sub-Saharan Africa: What Might the Future Hold? Virol Sin [Internet]. 2020;35(6):875-84. Available from: https://doi.org/10.1007/s12250-020-00279-2

6. Regional Office for Africa. Coronavirus (COVID-19) [Internet]. World Health Organization. 2020 [cited 2021 Feb 9]. Available from: https://www.afro.who.int/fr/node/12206

7. Dan-Nwafor C, Ochu CL, Elimian K, Oladejo J, Ilori E, Umeokonkwo C, et al. Nigeria's public health response to the COVID-19 pandemic: January to May 2020. J Glob Health. 2020;10(2).

8. Diop B, Faye A, Ndiaye EHM, Ndiaye M, Diallo JP, Diongue FB. Epidemic Trend of Corona Virus Disease 2019 (COVID-19) and Public Health Response in Senegal. 2020;2019:1-13.

9. Cabore JW, Karamagi HC, Kipruto H, Asamani JA, Droti B, Seydi ABW, et al. The potential effects of widespread community transmission of SARS-CoV-2 infection in the World Health Organization African Region: A predictive model. BMJ Glob Heal [Internet]. 2020 May 25 [cited 2021 Feb 9];5(5). Available from: /pmc/articles/PMC7252960/

10. World Health Organization. Infection prevention and control during health care when COVID-19 is suspected: interim guidance [Internet]. Geneva, Switzerland; 2020 [cited $2021 \mathrm{Feb} 9]$. Available from:

https://reliefweb.int/sites/reliefweb.int/files/resources/WHO-2019-nCoV-IPC-2020.3eng.pdf

11. World Health Organization. Infection prevention and control during health care when coronavirus disease (COVID-19) is suspected or confirmed: interim guidance, 29 June 2020 [Internet]. Geneva, Switzerland; 2020 [cited 2021 Feb 9]. Available from: https://apps.who.int/iris/bitstream/handle/10665/332879/WHO-2019-nCoV-IPC2020.4-eng.pdf? sequence $=1 \&$ isAllowed $=\mathrm{y}$

12. United Nations. Covid-19: WHO calls for stronger measures as cases rise in Africa [Internet]. UN Info. 2020 [cited $2021 \mathrm{Feb} 9$ ]. Available from: https://news.un.org/fr/story/2020/12/1084792

13. Regional Office for Africa. COVID-19 cases in Africa exceed 3 million, first wave peak reached [Internet]. World Health Organization. 2020 [cited 2021 Feb 9]. Available from: https://www.afro.who.int/fr/news/les-cas-de-covid-19-en-afriquedepassent-les-3-millions-le-pic-de-la-premiere-vague-est

14. Emergency Health Operations Centre. Standard Operating Procedure (SOP): MANAGEMENT OF SIMPLE CASES AT HOME IN THE CONTEXT OF COVID19. Dakar, Senegal; 2020.

15. Wilder-Smith A, Cook AR, Dickens BL. Institutional versus home isolation to curb the COVID-19 outbreak - Authors' reply. Lancet [Internet]. 2020 Nov 21 [cited 2020 Dec 
medRxiv preprint doi: https://doi.org/10.1101/2021.05.31.21258118; this version posted June 1, 2021. The copyright holder for this preprint (which was not certified by peer review) is the author/funder, who has granted medRxiv a license to display the preprint in perpetuity.

17];396(10263):1632-3. Available from:

https://www.thelancet.com/journals/lancet/article/PIIS0140-6736(20)32171-1/fulltext

16. Regional Office for Africa. New COVID-19 variants amplify second wave in Africa [Internet]. World Health Organization. 2021 [cited 2021 Feb 10]. Available from: https://www.afro.who.int/fr/news/les-nouveaux-variants-de-la-covid-19-amplifient-ladeuxieme-vague-en-afrique

17. Mason P, Pattillo C. Monetary Union in West Africa (ECOWAS): Is It Desirable and How Could It Be Achieved? [Internet]. International Monetary Fund. 2001 [cited 2021 Mar 15]. Available from: https://www.imf.org/external/pubs/nft/op/204/

18. United Nations. "Overall total population" - World Population Prospects: The 2019 Revision [Internet]. population.un.org. 2019 [cited 2021 Mar 15]. Available from: https://population.un.org/wpp/Download/Files/1_Indicators (Standard)/EXCEL_FILES/1_Population/WPP2019_POP_F01_1_TOTAL_POPULAT ION_BOTH_SEXES.xlsx

19. African Development Bank Group. West Africa Monitor Quarterly [Internet]. Abidjan; 2015 [cited 2021 May 14]. Available from:

https://www.afdb.org/fileadmin/uploads/afdb/Documents/Publications/L'West_Africa_ Monitor_N_5.pdf

20. Guidotti E, Ardia D. COVID-19 Data Hub. J Open Source Softw [Internet]. 2020 Jul 10 [cited 2021 Mar 15];5(51):2376. Available from:

https://joss.theoj.org/papers/10.21105/joss.02376

21. Bartoszek K, Guidotti E, Iacus SM, Okrój M. Are official confirmed cases and fatalities counts good enough to study the COVID-19 pandemic dynamics? A critical assessment through the case of Italy. Nonlinear Dyn [Internet]. 2020 Aug 1 [cited 2021 Mar 15];101(3):1951-79. Available from: /pmc/articles/PMC7319224/

22. Wikipedia. West Africa [Internet]. https://fr.wikipedia.org/. 2021 [cited 2021 Mar 15]. Available from: https://fr.wikipedia.org/wiki/Afrique_de_1\%27Ouest\#Économie

23. Cori A, Ferguson NM, Fraser C, Cauchemez S. A new framework and software to estimate time-varying reproduction numbers during epidemics. Am J Epidemiol [Internet]. 2013 Nov 1 [cited 2021 Mar 15];178(9):1505-12. Available from: https://academic.oup.com/aje/article-lookup/doi/10.1093/aje/kwt133

24. Nishiura H, Linton NM, Akhmetzhanov AR. Serial interval of novel coronavirus (COVID-19) infections. Int J Infect Dis. 2020 Apr 1;93:284-6.

25. COVID-19 Africa. COVID-19 documents [Internet]. 2021 [cited 2021 May 15]. Available from: https://www.covid19afrique.com/documents-covid-19

26. Bonnet E, Sambieni E, Fournet F, Boyer F. The COVID-19 Pandemic in Francophone West Africa: From the First Cases to Responses in Seven Countries. Res Sq. 2020;14.

27. Worldometer. Coronavirus Update (Live): Cases and Deaths from COVID-19 Virus Pandemic [Internet]. 2021 [cited 2021 Feb 11]. Available from:

https://www.worldometers.info/coronavirus/

28. Johns Hopkins. Mortality Analyses - Coronavirus Resource Center [Internet]. https://coronavirus.jhu.edu/. 2021 [cited 2021 Mar 18]. Available from:

https://coronavirus.jhu.edu/data/mortality

29. WHO RO for A. Rising mortality as Africa marks one year of COVID-19 [Internet]. https://www.afro.who.int/. 2021 [cited 2021 Mar 18]. Available from: https://www.afro.who.int/news/rising-mortality-africa-marks-one-year-covid-19

30. World Health Organization. Health status in the WHO African Region, Analysis of health status, services and systems in the context of sustainable development goals [Internet]. Geneva, Switzerland; 2021 [cited 2021 Mar 18]. Available from: https://apps.who.int/iris/bitstream/handle/10665/275278/9789290313076- 
medRxiv preprint doi: https://doi.org/10.1101/2021.05.31.21258118; this version posted June 1,2021 . The copyright holder for this preprint (which was not certified by peer review) is the author/funder, who has granted medRxiv a license to display the preprint in perpetuity.

It is made available under a CC-BY-NC-ND 4.0 International license .

fre.pdf?sequence $=1 \&$ isAllowed $=\mathrm{y}$

31. World Bank. Africa - Overview [Internet]. https://www.banquemondiale.org/. 2020 [cited 2021 Mar 18]. Available from: https://www.banquemondiale.org/fr/region/afr/overview\#2

32. Reuters. Cape Verde: The latest figures, charts and maps on the evolution of the coronavirus [Internet]. https://graphics.reuters.com/. 2021 [cited 2021 Apr 18]. Available from: https://graphics.reuters.com/world-coronavirus-tracker-andmaps/fr/countries-and-territories/cape-verde/

33. Bognanni A, Schiaffino A, Pimpinelli F, Donzelli S, Celesti I, Strano S, et al. The Conundrum of Giglio Island: Unraveling the dynamics of an apparent resistance to COVID-19 - A descriptive study. Comput Struct Biotechnol J. 2021 Jan 1;19:1467-71.

34. TV5MONDE. Coronavirus in Africa: which countries vaccinate? [Internet]. https://information.tv5monde.com/afrique/. 2021 [cited 2021 Mar 18]. Available from: https://information.tv5monde.com/afrique/coronavirus-en-afrique-quels-paysvaccinent-393984

35. World Health Organization. COVAX releases list of first round of vaccine awards [Internet]. https://www.who.int/fr/. 2021 [cited 2021 Mar 18]. Available from: https://www.who.int/fr/news/item/02-03-2021-covax-publishes-first-round-ofallocations 
medRxiv preprint doi: https://doi.org/10.1101/2021.05.31.21258118; this version posted June 1, 2021. The copyright holder for this preprint (which was not certified by peer review) is the author/funder, who has granted medRxiv a license to display the preprint in perpetuity.

It is made available under a CC-BY-NC-ND 4.0 International license.

Appendix 1: Dynamics of confirmed COVID-19 cases

\begin{tabular}{|lcccc|}
\hline Country & $\begin{array}{c}\text { Confirmed cases (October } \\
\mathbf{2 0 2 0} / \text { November 2020) }\end{array}$ & $\begin{array}{c}\text { Confirmed cases (December } \\
\mathbf{2 0 2 0 / J a n u a r y ~ 2 0 2 1})\end{array}$ & $\begin{array}{c}\text { Rate of change } \\
(\mathbf{\%})\end{array}$ & $\mathbf{R}_{\mathbf{e}}[\mathbf{9 5 \%}$ CI $]$ \\
\hline Senegal & 1107 & 10434 & 842,55 & $1,02[0,97-1,07]$ \\
\hline Nigeria & 8709 & 63685 & 631,26 & $0,88[0,86-0,90]$ \\
\hline Mauritania & 1099 & 8034 & 631,03 & $0,77[0,67-0,87]$ \\
\hline Mali & 1592 & 3381 & 112,37 & $0,78[0,64-0,94]$ \\
\hline Cape Verde & 4737 & 3309 & $-30,15$ & $1,15[1,05-1,25]$ \\
\hline West Africa & $\mathbf{3 0 1 0 1}$ & $\mathbf{1 2 8 4 9 0}$ & $\mathbf{3 2 6 , 8 6}$ & $\mathbf{1 , 0 5}[\mathbf{1 , 0 4}-\mathbf{1 , 0 7}]$ \\
\hline
\end{tabular}

Appendix 2: COVID-19 death dynamics

\begin{tabular}{|lccc|}
\hline country & $\begin{array}{c}\text { Deaths (October 2020/November } \\
\mathbf{2 0 2 0})\end{array}$ & $\begin{array}{c}\text { Deaths (December 2020/January } \\
\mathbf{2 0 2 1})\end{array}$ & $\begin{array}{c}\text { Rate of change } \\
(\mathbf{\%})\end{array}$ \\
\hline Senegal & 22 & 295 & 1240,91 \\
\hline Nigeria & 61 & 413 & 577,05 \\
\hline Mauritania & 16 & 245 & 1431,25 \\
\hline Mali & 25 & 174 & 596,00 \\
\hline Cape Verde & 45 & 29 & $-35,56$ \\
\hline West Africa & $\mathbf{2 6 3}$ & $\mathbf{1 4 5 0}$ & $\mathbf{4 5 1 , 3 3}$ \\
\hline
\end{tabular}

